RESEARCH REPORT

\title{
Risk modifying effect of social capital on measures of heavy alcohol consumption, alcohol abuse, harms, and secondhand effects: national survey findings
}

\author{
Elissa R Weitzman, Ying-Yeh Chen
}

J Epidemiol Community Health 2005;59:303-309. doi: 10.1136/jech.2004.024711

\begin{abstract}
See end of article for authors' affiliations

Correspondence to: Dr E R Weitzman, Department of Society, Human Development and Health, Harvard School of Public Health, 401 Park Drive, PO Box 15678, Boston, MA 02215, USA; eweitzma@hsph.harvard. edu
\end{abstract}

Accepted for publication 13 October 2004

\begin{abstract}
Study objective: To examine associations between social capital and individual risk for alcohol abuse and harms and identify protective effect mechanisms.

Design: Multilevel multivariate analysis with individual level data from a national panel survey of drinking and a contextual measure of social capital reflecting college mean aggregate reports of student volunteerism. Outcomes include heavy episodic (binge) drinking, frequent drinking, frequent drunkenness, diagnosable alcohol abuse, intentional drunkenness, acquisition of binge drinking, harms, secondhand effects from others' drinking.

Setting: United States, 119 four year colleges.

Participants: Representative samples of youth ages 18-24 surveyed in 1997 and 1999 using an anonymous mailed questionnaire (total $n=27687$ ).

Main results: Students from colleges with higher levels of social capital reported reduced risks for binge drinking (adjusted $\mathrm{OR} 0.38,95 \% \mathrm{Cl} 0.20$ to $0.69, \mathrm{p}=0.002$ ), frequent drunkenness (adjusted $\mathrm{OR} 0.58$, $95 \% \mathrm{Cl} 0.34$ to $0.98, p=0.04$ ), acquisition of binge drinking in college (adjusted OR $0.48,95 \% \mathrm{Cl} 0.24$ to $0.95, p=0.03$ ), and alcohol abuse (adjusted $\mathrm{OR} 0.55,95 \% \mathrm{Cl} 0.34$ to $0.91, p=0.02$ ) in multilevel multivariate analyses that controlled for individual volunteering, the measure on which social capital was based. Higher levels of social capital protected against multiple drinking related harms (adjusted OR 0.51, $95 \% \mathrm{Cl} 0.29$ to $0.90, \mathrm{p}=0.02$ ) and secondhand drinking effects (adjusted $\mathrm{OR}, 0.30,95 \% \mathrm{Cl} 0.16$ to 0.58 , $p=0.0003$ ). Significant cross level interactions exist between fraternity/sorority membership and social capital for measures of risky drinking. Harm reduction primarily reflects consumption modification. Conclusions: Social capital exerts strong protective effects on alcohol abuse and harm in college including among high risk students.
\end{abstract}


Table 1 DSM-IV alcohol abuse criteria from 1997 and 1999 CAS survey items

\begin{tabular}{ll}
\hline DSM-IV criteria & CAS measure of harm \\
\hline Failure to fulfill important social role & $\begin{array}{l}\text { Missed class and } \\
\text { Fell behind in school work }\end{array}$ \\
Use alcohol despite physically & Alcohol related injury or \\
hazardous context & Alcohol related overdose or \\
& Drive and heavy episodic drink \\
Legal problems associated with & Damaged property or \\
alcohol use & Trouble with police \\
Continued use despite persistent & Argued with friends or \\
social or interpersonal problems & Did something later regretted \\
\hline
\end{tabular}

alcohol abuse, reports of primary and secondhand harms related to alcohol consumption. A broad protective effect would be consistent with our conceptualisation of social capital that draws on collective socialisation and social development models ${ }^{28} 29$ to predict that communities rich in social capital will promote greater attachment among youth for the larger community, norms that heavy drinking and drunkenness are not acceptable, and compliance with laws and policies restricting drinking among youth. The net effect of these forces is expected to be lower individual risks for heavy and abusive drinking and related harms. This study also sought to identify whether any observed reduction in harms (primary or secondhand) associated with social capital would be realised as a consequence of reductions in consumption or other individual or contextual factors not captured in the relation between social capital and consumption. Finally, this study sought to identify variations in effect for students affiliated with campus fraternity and sorority (or Greek) organisations at high and low social capital campuses. These organisations were originally formed to promote social support and advancement among students and can include a service component. Nevertheless, Greek membership confers considerable risk for heavy drinking and harms and Greek organisations are often at the centre of alcohol abuse problems on campus. ${ }^{30}$ Exploring whether excess drinking risks among fraternity/sorority members can be offset by exposure to social capital may help clarify the magnitude and homogeneity of any protective effect.

\section{METHODS}

\section{Sources of data}

This study draws on data from the 1997 and 1999 Harvard School of Public Health College alcohol study (CAS), an anonymous self report mailed survey that has been administered four times to a nationally representative sample of American college students. It was originally administered in 1993 to random samples of full time undergraduate students at a sample of 140 four year colleges and universities. ${ }^{31}$ Random samples of students were surveyed at 130 of 140 original schools in 1997 and at 128 of the schools in $1999 .{ }^{32}$ The total sample size combining 1997 and 1999 was 28862 . After excluding schools with response rates lower than $50 \%$, the final sample size used in this study was 27687 from 119 schools. Detailed survey methodology has been published elsewhere. ${ }^{31}{ }^{32}$ Protocols for both national surveys on which this research is based were reviewed and approved by the HSPH Office of Human Subjects Research.

\section{Outcome measures}

Four categories of alcohol related outcomes are reported: (1) alcohol abuse; (2) alcohol consumption patterns; (3) alcohol related harms; (4) secondhand effect of others' drinking. To measure alcohol abuse, we adapted the Diagnostic and
Statistical Manual of Mental Disorders-fourth edition (DSM-IV) ${ }^{33}$ alcohol abuse criteria to the college setting following previously published methods ${ }^{34}$ in which each of four alcohol abuse criteria was matched to self reports of specific drinking harms over the past academic year as they affected respondents' primary social role as student (table 1). Next we assessed six measures of alcohol consumption. Among students who had at least one drink in the past month we examined: drinking on 10 or more occasions during the past month, usual number of drinks consumed on a drinking occasion (five or more compared with fewer than five), experiencing drunkenness three or more times in the past month, and drinking in order to get drunk. For all students we evaluated binge drinking status, defined as the consumption of five or more drinks in a row at least once in the past two weeks for men and four or more drinks in a row for women. ${ }^{35}$ We also assessed taking up binge drinking in college among freshman who reported they were not binge drinkers in high school. ${ }^{12}$

Experience of drinking related harms was evaluated since the beginning of the school year, including reports students: had a hangover; missed a class; fell behind in schoolwork; did something they later regretted; forgot where they were or what they did; argued with friends; engaged in unplanned sexual activity; did not use protection when having sex; damaged property; got into trouble with campus or local police; got hurt or injured; required medical treatment for an alcohol overdose. A composite variable was also created describing experience of five or more of the above mentioned harms as an indication of the intensity of harms from drinking in this population consistent with other studies. ${ }^{36}$

Among non-binge drinkers we assessed experience since the beginning of the school year of eight adverse effects attributable to others' drinking including reports students: were insulted or humiliated; had a serious argument or quarrel; had been pushed, hit, or assaulted; had their property damaged; had to "babysit" or take care of another student who drank too much; had their studying or sleep interrupted; experienced an unwanted sexual advance; or, had been a victim of sexual assault or date rape. A composite variable describing experiencing of three or more of the above mentioned secondhand effects of others' drinking was also examined. Use of a three or more secondhand effects measure provides an indication of the intensity of community harms from others' drinking in this population consistent with other studies. ${ }^{37}$

\section{Independent variables}

Social capital was operationalised as a continuous variable assessing particapants' average daily time committed to volunteering in the past 30 days aggregated to the campus level. The time spent in volunteerism at the school level reflects a core feature of the social capital construct-its "public good" element, and shows the students' dedication to the group or collective. ${ }^{16}{ }^{23}$ Within the college population in which time may be tight and youth may exhibit both their idealism and norms about reciprocity and engagement through volunteerism, the mean aggregate levels of voluntary behaviour at the community level may be a meaningful indicator of social capital on a campus. We used a parsimonious contextual measure created from this single variable to describe social capital. Other related variables describing participation in student groups and political organisations did not improve the reliability of the estimate of social capital when composited with the variable on voluntary behaviour and measured contextually. Individual volunteerism (h/day) was included as a control variable. Also included in the models were individual level covariates that 
Table 2 Social demographic characteristics, alcohol use/abuse and drinking related harms of a nationally representative sample of college students in 1997 and 1999

\begin{tabular}{|c|c|c|c|c|c|c|c|c|c|c|}
\hline \multirow[b]{2}{*}{ Variables } & \multirow[b]{2}{*}{$\begin{array}{l}\text { Number } \\
\text { (weighted\%) }\end{array}$} & \multirow[b]{2}{*}{$\begin{array}{l}\text { Alcohol abuse } \\
\text { (weighted } \\
\text { \%) }\end{array}$} & \multicolumn{6}{|c|}{ Consumption styles (weighted \%) } & \multirow[b]{2}{*}{$\begin{array}{l}\text { Five or more } \\
\text { harmst } \\
\text { (weighted \%) }\end{array}$} & \multirow{2}{*}{$\begin{array}{l}\text { Three or more } \\
\text { secondhand effect‡ } \\
\text { (among non-bingers) } \\
\text { (weighted \%) }\end{array}$} \\
\hline & & & $\begin{array}{l}\text { Drinking on 10+ } \\
\text { occasions in the } \\
\text { past month }\end{array}$ & $\begin{array}{l}\text { Usually } \\
\text { binge }\end{array}$ & $\begin{array}{l}\text { Drunk on 3+ } \\
\text { occasions in } \\
\text { the past month }\end{array}$ & $\begin{array}{l}\text { Drink to } \\
\text { get drunk }\end{array}$ & $\begin{array}{l}\text { Binge drinking } \\
\text { in college }\end{array}$ & $\begin{array}{l}\text { Uptake binge } \\
\text { drinking in college } \\
\text { (among freshman) }\end{array}$ & & \\
\hline \multicolumn{11}{|l|}{ Age } \\
\hline$<21$ & $13652(49.24)$ & $25.34^{* \star *}$ & $21.90^{* * *}$ & $54.11^{\star * *}$ & $35.52^{* * *}$ & $60.41^{* * *}$ & $45.34^{* * *}$ & $18.41^{* * *}$ & $23.05^{* * *}$ & $38.43^{* * *}$ \\
\hline $21-23$ & $9523(35.40)$ & 24.34 & 25.39 & 37.82 & 29.02 & 48.14 & 49.62 & 16.36 & 21.65 & 27.91 \\
\hline$>23$ & $4426(15.36)$ & 11.17 & 16.49 & 24.43 & 13.13 & 26.36 & 29.15 & 13.01 & 10.15 & 12.77 \\
\hline \multicolumn{11}{|l|}{ Sex } \\
\hline Male & $10841(46.56)$ & $27.17^{* * *}$ & $29.32^{* * *}$ & $45.30^{* * *}$ & $35.21^{* * *}$ & $56.78^{* * *}$ & $49.80^{* * *}$ & 18.37 & $25.58^{* * *}$ & 30.40 \\
\hline Female & $16741(53.44)$ & 19.20 & 16.09 & 41.95 & 24.84 & 45.67 & 39.66 & 18.11 & 16.35 & 29.83 \\
\hline \multicolumn{11}{|l|}{ Race } \\
\hline White & $21121(76.62)$ & $25.92^{\star \star *}$ & $24.41^{* * *}$ & $46.35^{\star \star *}$ & $32.60^{* * *}$ & $53.89^{* * *}$ & $49.50^{* * *}$ & $19.29^{* * *}$ & $22.69^{* * *}$ & $31.63^{* * *}$ \\
\hline Black & $1615(6.07)$ & 9.44 & 8.53 & 21.56 & 8.98 & 30.42 & 18.39 & 11.08 & 8.56 & 26.32 \\
\hline Asian & $2174(8.48)$ & 11.26 & 10.36 & 30.64 & 19.71 & 43.06 & 23.98 & 12.69 & 11.83 & 24.68 \\
\hline Others & $2217(8.84)$ & 19.17 & 19.11 & 36.83 & 20.56 & 41.34 & 38.95 & 21.42 & 12.64 & 29.65 \\
\hline \multicolumn{11}{|l|}{ SES } \\
\hline High & $15008(54.60)$ & $24.95^{* * *}$ & $24.65^{* * *}$ & 43.99 & $32.24^{* * *}$ & $54.62^{* * *}$ & $47.63^{* * *}$ & $20.10^{* * *}$ & $22.06^{* * *}$ & $34.05^{* * *}$ \\
\hline Middle & $6991(25.24)$ & 23.11 & 20.87 & $44.66^{* * *}$ & 28.21 & 48.42 & 44.11 & 17.03 & 20.92 & 28.08 \\
\hline Low & $5258(18.59)$ & 17.55 & 17.97 & 41.11 & 24.68 & 43.04 & 35.82 & 13.83 & 16.04 & 23.28 \\
\hline \multicolumn{11}{|c|}{$\begin{array}{l}\text { Greek } \\
\text { membership }\end{array}$} \\
\hline Yes & $3700(13.81)$ & $37.42^{\star \star \star *}$ & $31.19^{* * *}$ & $54.98^{* * *}$ & $42.06^{* * *}$ & $59,49^{\star \star *}$ & $67.44^{* * *}$ & $25.45^{* * *}$ & $32.67^{\star \star *}$ & $45.67^{\star \star \star}$ \\
\hline No & $23836(86.19)$ & 20.59 & 20.68 & 41.17 & 27.27 & 49.20 & 40.70 & 17.24 & 18.33 & 28.69 \\
\hline \multicolumn{11}{|c|}{$\begin{array}{l}\text { Individual } \\
\text { volunteerism }\end{array}$} \\
\hline$>$ mean & $6982(24.45)$ & $18.06^{* * *}$ & $18.71^{* * *}$ & $39.16^{* * *}$ & $24.89^{* * *}$ & $44.62^{* * *}$ & $37.55^{* * *}$ & $14.84^{* * *}$ & $17.41^{* * *}$ & $33.40^{* * *}$ \\
\hline$\leqslant$ mean & $20705(75.55)$ & 24.44 & 23.55 & 44.80 & 31.23 & 52.61 & 46.60 & 19.11 & 21.56 & 28.82 \\
\hline \multicolumn{11}{|c|}{ Social capital } \\
\hline$>$ mean & $11803(42.60)$ & $25.99^{* * *}$ & $20.32^{* *}$ & $40.48^{* * *}$ & $26.21^{* * *}$ & $47.15^{* \star *}$ & $39.18^{* * *}$ & $16.81^{*}$ & $17.58^{* * *}$ & $25.76^{* * *}$ \\
\hline$\leqslant$ mean & $15884(57.40)$ & 29.83 & 22.21 & 44.79 & 30.29 & 51.43 & 46.79 & 19.01 & $21.08^{* * *}$ & 32.90 \\
\hline
\end{tabular}

may affect volunteerism or alcohol use such as age, sex, race (white compared with non-white), socioeconomic status (SES) (operationalised as parental educational attainment-high: both parents had college education, middle: either father or mother had college education, low: neither parents went to college), and fraternity or sorority membership. The analysis also adjusted for school level characteristics including public compared with private institution, enrolment size, geographical region, and response rate.

\section{Analysis}

Multilevel logistic regression models based on a logit-link function were used ${ }^{38}$ to take into account the potential for individual outcomes to cluster by campus. All the analyses were fitted using MLwin multilevel software (version 1.10.0006) $)^{39}$ with marginal quasilikelihood (MQL) first order estimation procedures being applied. We first present the basic demographic characteristics. Then, a two level random intercept model with individual students at level 1 , nested within colleges at level 2 was fit to assess the effect of school social capital on dichotomised alcohol related outcomes controlling for individual and school level covariates. Effects of social capital on drinking related harms and secondhand effects were estimated before and after controlling for patterns of consumption at individual and college levels respectively to assess the degree to which any protective effects of social capital on harms operated independently of consumption.

To test whether social capital modified the risk of alcohol abuse among Greek affiliated students, we tested the cross level interaction between Greek membership and campus social capital on study outcomes, controlling for all relevant individual and college covariates and for the main effects of individual volunteering and Greek membership. We also

Table 3 Social capital predicting alcohol abuse and consumption style

\begin{tabular}{|c|c|c|}
\hline & ORt & $95 \% \mathrm{Cl}$ \\
\hline $\begin{array}{l}\text { Alcohol abuse criteria } \\
\text { Social role failure } \\
\text { Drinking despite hazard context } \\
\text { Drinking causes legal problems } \\
\text { Drinking causes social/interpersonal problems } \\
\text { Satisfy DSM-IV alcohol abuse criteria } \\
\text { Alcohol consumption style } \\
\text { Drinking on } 10 \text { or more occasions in the past month } \\
\text { Usually binge } \\
\text { Drunk on } 3 \text { or more occasions in the past month } \\
\text { Drink to get drunk } \\
\text { Binge drinking } \\
\text { Uptake binge drinking in college } \ddagger\end{array}$ & $\begin{array}{l}0.73 \\
0.50^{\star} \\
0.54 \\
0.56^{\star} \\
0.55^{*} \\
\\
0.90 \\
0.72 \\
0.58^{*} \\
0.70^{+} \\
0.38^{* *} \\
0.48^{*}\end{array}$ & $\begin{array}{l}(0.39 \text { to } 1.37) \\
(0.28 \text { to } 0.91) \\
(0.24 \text { to } 1.23) \\
(0.33 \text { to } 0.93) \\
(0.34 \text { to } 0.91) \\
(0.55 \text { to } 1.47) \\
(0.44 \text { to } 1.19) \\
(0.34 \text { to } 0.98) \\
(0.46 \text { to } 1.06) \\
(0.20 \text { to } 0.69) \\
(0.24 \text { to } 0.95)\end{array}$ \\
\hline
\end{tabular}



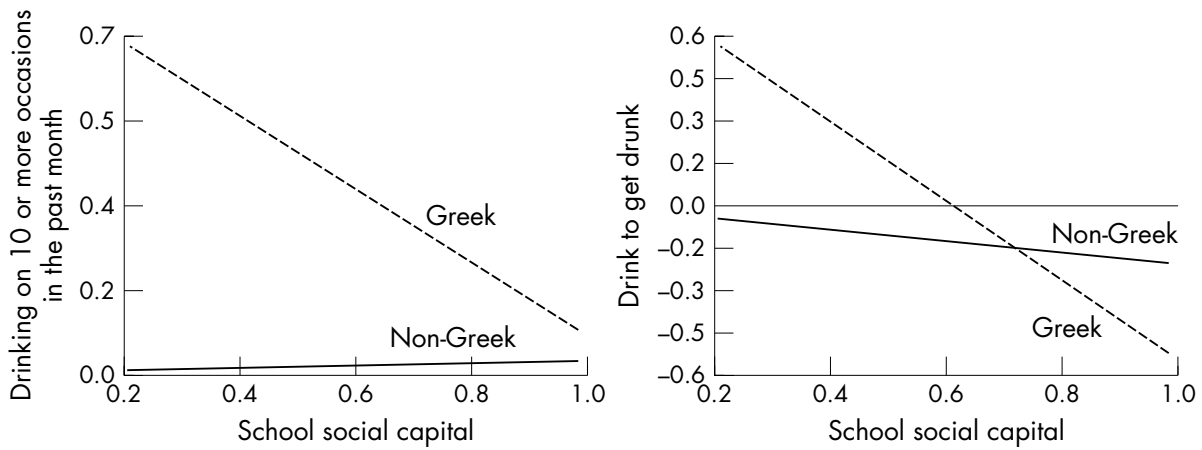

Figure 1 Cross level interaction between Greek membership and school social capital on individual risk for each of four measures of alcohol consumption. ${ }^{*} \mathrm{p}<0.05$.
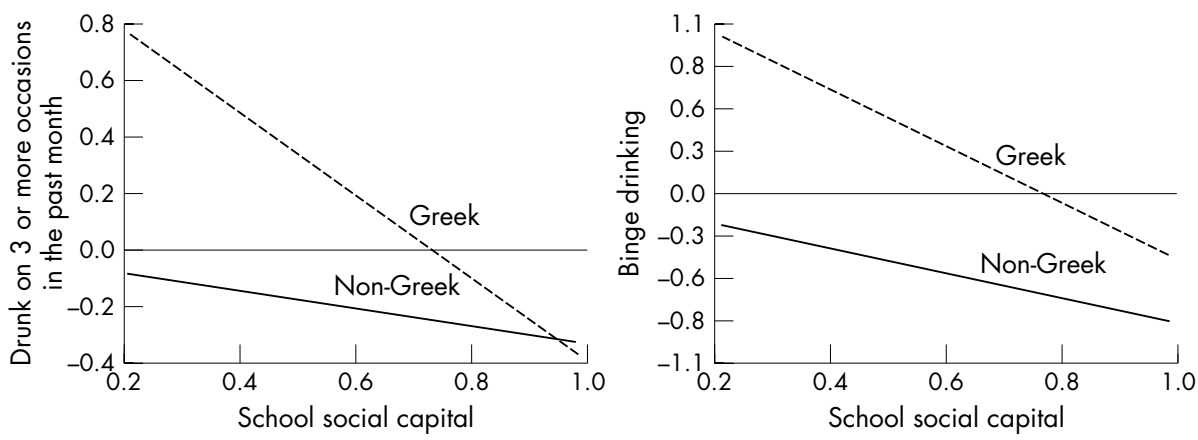

tested whether risks for alcohol abuse were related to the interaction between individual volunteerism and Greek membership.

All analyses were done on study data weighted according to the actual age, gender, and racial/ethnic distributions of each school to control for variations in underlying population characteristics and potential unmeasured selection effects, consistent with procedures reported for national trend analyses. $^{32}$

\section{RESULTS}

The average daily time committed to volunteering for all respondents was about 0.45 hour, or 27 minutes, ranging from 0 to 5 hours $(\mathrm{SD}=1.01)$. At the campus level, the

Table 4 Social capital predicting drinking related harms and second hand effects

\begin{tabular}{|c|c|c|c|c|}
\hline & \multicolumn{2}{|c|}{ Before adjusting for consumption } & \multicolumn{2}{|c|}{ After adjusting for consumption } \\
\hline & ORt & $95 \% \mathrm{Cl}$ & OR $\ddagger$ & $95 \% \mathrm{Cl}$ \\
\hline $\begin{array}{l}\text { Drinking related harms } \\
\text { Hangover } \\
\text { Miss class } \\
\text { Get behind in school work } \\
\text { Do something later regretted } \\
\text { Black out } \\
\text { Argue with friends } \\
\text { Engage in unplanned sexual activity } \\
\text { Unprotected sex } \\
\text { Damage property } \\
\text { Get into trouble with the campus or local police } \\
\text { Get hurt or injured } \\
\text { Required medical treatment for an alcohol overdose } \\
\text { Having five or more above mentioned harm } \\
\text { Secondhand effects of others' drinking } \$ \\
\text { Been insulted or humiliated } \\
\text { Had a serious argument or quarrel } \\
\text { Been pushed, hit, or assaulted } \\
\text { Had your property damaged } \\
\text { Had to take care of another student who drunk } \\
\text { Found vomit in the residence } \\
\text { Had study or sleep interrupted } \\
\text { Experienced an unwanted sexual advance } \\
\text { Been a victim of sexual assault } \\
\text { Been a victim of another crime on campus } \\
\text { Been a victim of another crime off campus } \\
\text { Having } 3+\text { above mentioned secondhand effects }\end{array}$ & $\begin{array}{l}0.51^{* *} \\
0.74 \\
0.77 \\
0.67^{+} \\
0.53^{*} \\
0.70+ \\
0.78 \\
1.26 \\
0.72 \\
0.62 \\
0.43^{* *} \\
0.75 \\
0.51^{*} \\
O R \\
0.44^{* *} \\
0.60^{*} \\
0.51^{*} \\
0.28^{* * *} \\
0.41^{* * *} \\
0.18^{* * *} \\
0.19^{* * *} \\
0.48^{*} \\
0.33 \\
0.33 \\
1.44 \\
0.30^{* * *}\end{array}$ & $\begin{array}{l}(0.31 \text { to } 0.81) \\
(0.44 \text { to } 1.26) \\
(0.50 \text { to } 1.20) \\
(0.45 \text { to } 1.02) \\
(0.32 \text { to } 0.88) \\
(0.46 \text { to } 1.07) \\
(0.51 \text { to } 1.21) \\
(0.78 \text { to } 2.06) \\
(0.40 \text { to } 1.31) \\
(0.29 \text { to } 1.34) \\
(0.23 \text { to } 0.80) \\
(0.16 \text { to } 3.45) \\
(0.29 \text { to } 0.90) \\
95 \% \text { Cl } \\
(0.27 \text { to } 0.75) \\
(0.36 \text { to } 0.99) \\
(0.28 \text { to } 0.91) \\
(0.14 \text { to } 0.55) \\
(0.24 \text { to } 0.69) \\
(0.08 \text { to } 0.41) \\
(0.09 \text { to } 0.41) \\
(0.29 \text { to } 0.77) \\
(0.09 \text { to } 1.16) \\
(0.08 \text { to } 1.36) \\
(0.51 \text { to } 4.09) \\
(0.16 \text { to } 0.58)\end{array}$ & $\begin{array}{l}0.59^{*} \\
0.91 \\
1.04 \\
0.84 \\
0.62^{\star} \\
0.82 \\
0.91 \\
1.45 \\
0.84 \\
0.58 \\
0.47^{* *} \\
1.47 \\
0.68 \\
08^{\star} \\
0.80 \\
0.92 \\
0.88 \\
0.59+ \\
0.79 \\
0.47^{*} \\
0.53^{\star} \\
0.73 \\
0.32 \\
0.41 \\
1.40 \\
0.72\end{array}$ & $\begin{array}{l}(0.39 \text { to } 0.88) \\
(0.57 \text { to } 1.48) \\
(0.72 \text { to } 1.50) \\
(0.59 \text { to } 1.19) \\
(0.40 \text { to } 0.97) \\
(0.56 \text { to } 1.20) \\
(0.62 \text { to } 1.36) \\
(0.90 \text { to } 2.34) \\
(0.50 \text { to } 1.43) \\
(0.28 \text { to } 1.21) \\
(0.27 \text { to } 0.80) \\
(0.27 \text { to } 7.90) \\
(0.41 \text { to } 1.11) \\
95 \% \text { Cl } \\
(0.52 \text { to } 1.24) \\
(0.57 \text { to } 1.47) \\
(0.52 \text { to } 1.51) \\
(0.34 \text { to } 1.03) \\
(0.51 \text { to } 1.22) \\
(0.22 \text { to } 0.99) \\
(0.28 \text { to } 0.99) \\
(0.46 \text { to } 1.16) \\
(0.08 \text { to } 1.22) \\
(0.09 \text { to } 1.86) \\
(0.45 \text { to } 4.37) \\
(0.43 \text { to } 1.20)\end{array}$ \\
\hline
\end{tabular}


aggregated levels of volunteerism ranged from 0.25 hour (15 minutes) to 0.98 hour (about 1 hour), with a mean of 0.46 hour, or about 28 minutes $(S D=0.14)$. Individual volunteerism was minimally correlated with campus levels of volunteerism (our measure of social capital) $(r=0.14$, $\mathrm{p}<0.0001$ ). Considerable variation at the college level was evident across measures of drinking style. Across the 119 surveyed colleges, we observed the average prevalence, range, and standard deviation of alcohol abuse, frequent drinking, frequent drunkenness, and binge drinking to be respectively: $27.8 \%(0.26 \%-53 \%)$ standard deviation $10.6 \% ; 14.0 \%(0 \%-$ $34.2 \%)$, standard deviation $6.9 \% ; 18.2 \%(0 \%-47.49 \%)$, standard deviation $9.9 \% ; 43.9 \%(0 \%-79.8 \%)$, standard deviation $14.7 \%$.

Overall, women, non-white students, older aged $(>23$ years), or students from lower socioeconomic status backgrounds were less likely to use/abuse alcohol, report drinking related harms, or experience secondhand effects; while fraternity/sorority or Greek membership were associated with higher odds of drinking problems, alcohol related harms, or secondhand effects (table 2). Students who spent more time on volunteer work were less likely to use or abuse alcohol, or report drinking related harms. However, they were more likely to experience secondhand effects of other students' drinking. Students attending schools with high levels of social capital were less likely to report heavy and abusive drinking, drinking related harms, and secondhand effects. Protective effects of social capital on alcohol abuse, acquisition, or uptake of binge drinking, frequent and intentional drunkenness persisted after controlling for a range of individual and contextual characteristics and for individual time volunteering (table 3). For example, each one hour increase in aggregated levels of campus volunteerism corresponded to a $45 \%$ decrease in the probability of having an alcohol abuse disorder among college students (adjusted odds ratio $=0.55,95 \%$ confidence intervals 0.34 to 0.91 ), after adjustment for age, sex, race, SES, students' membership, and school characteristics. Based on this, a one quarter hour increase in aggregated levels of campus volunteerism would decrease college students' alcohol abuse by more than $11 \%$.

Significant cross levels interactions exist between social capital and Greek membership for four alcohol related outcomes-binge drinking, frequent binge drinking, intentional, and frequent drunkenness. Increased risk for these

\section{Key points}

- Among a nationally representative sample of young adults in college in the United States, exposure to high contextual levels of social capital was associated with significantly lower individual risk for measures of abuse and DSM-IV abuse of alcohol, drinking related harms, and secondhand effects from others' drinking.

- Additionally, increased odds for alcohol abuse among high risk fraternity/sorority affiliated students was significantly offset by exposure to social capital rich communities.

- The protective effect of social capital on drinking harms and secondhand effects was attributable almost entirely to its moderating effects on consumption. Social capital rich communities in which many youth volunteer protect against alcohol abuse and harms, among the most common and serious health issues facing young populations. outcomes among Greek affiliated students was reduced to that of their non-Greek peers when levels of school social capital were high (fig 1). There were no interactions between Greek membership and individual volunteering for these or other drinking outcomes.

Higher levels of school social capital were associated with decreased probabilities of several drinking related harms (table 4). For each one hour increase in aggregate school level volunteerism we would expect a $49 \%$ decrease in reporting harms associated with alcohol use $(\mathrm{OR}=0.5 \mathrm{l}, 95 \%$ confidence interval $=0.29$ to 0.90 ). By this measure, a one quarter hour increase in aggregated levels of campus volunteerism would decrease college students' alcohol related harm more than $12 \%$. Protective effects on drinking related harms were attenuated by controlling for measures of drinking style (second set of data columns, table 4) showing that social capital's protective effect on harms operates mainly through modifying consumption.

After controlling for individual and school characteristics, students attending colleges with higher levels of social capital were also less likely to suffer from the consequences of other students' drinking problems (table 4). Each one hour increase in campus social capital was associated with a $70 \%$ reduced probability of suffering from secondary harms of other students drinking ( $\mathrm{OR}=0.30,95 \%$ confidence interval $=0.16$ to 0.58 ). Based on this, we would expect to see more than a $17 \%$ decrease in alcohol related secondhand effects among non-bingers if campus levels volunteerism increased by one quarter hour. Diminution of secondhand effects after controlling for drinking style (second set of data columns, table 4) suggests that social capital's protective effect operates mainly through consumption.

\section{DISCUSSION}

Students from colleges with higher levels of social capital reported reduced risks for binge drinking, frequent and intentional drunkenness, the acquisition or uptake of binge drinking in college, and patterns of alcohol abuse indicative of a more serious psychiatric problem in multilevel analyses that take into consideration the effects of demographic, social network, affiliative, and institutional characteristics, and that simultaneously control for individual patterns of voluntary activity, the measure on which social capital was based. Findings are consistent with earlier reports ${ }^{23}$ and with our hypothesis about the role of social capital in protecting against deviance and threat, as shown by more problematic drinking styles. Exposure to higher levels of social capital was also associated with lower odds of experiencing a range of drinking related harms, multiple harms, secondhand effects from others' drinking, and multiple secondhand effects. The protective effects of social capital on outcomes operated mainly through moderating consumption as evidenced by attenuated effects of social capital on harms after controlling for consumption (table 4).

Increased risks for heavy and frequent drinking, intentional and frequent drunkenness among Greek affiliated students was almost fully offset by exposure to high levels of social capital at the campus community level (fig 1). This effect was evident after controlling for individual voluntary activity, for which there was no parallel interaction with Greek affiliation.

Findings answer questions about the consistency of social capital's risk modifying effect on consumption by examining its effects across a range of drinking measures. They also show social capital's protective effect on harms. Questions about underlying mechanisms remain. We do not yet understand why social capital depresses drinking and we know nothing about whether it can be generated, supported, or harnessed to intentionally aid prevention. Future work 
might well address the interrelation of social capital with other factors including alcohol policies and prevention programmes and with academic and social requirements for volunteering and community service, and explore protective effects for other subgroups of youth. ${ }^{30}$ Additional work might also use operational definitions of social capital that tap different components of the construct.

Findings that risk associated with fraternity/sorority association can be offset by exposure to high levels of social capital emphasise the power of this construct and importance of considering individual and environmental interactions. These findings and the ongoing debate about social capital's potential to exclude, "bond", or "bridge" groups ${ }^{15} 40$ suggest examining effects among lesser status groups, including racial and ethnic minority students. We think that higher levels of social capital in college communities signal more egalitarian and therefore healthier places where psychological needs for drinking are fewer, as findings about social capital's protective effects on intentional drunkenness suggest. Findings about the protective effects of campus demographic diversity on drinking and harms among both majority and minority students in college support the potential for this more positive interpretation. ${ }^{41}$

Confidence in this study's findings is increased given our large representative survey sample, multiple measures of alcohol consumption and harm, and use of an established if single indicator of social capital. Nevertheless, we cannot generalise results beyond four year US colleges. Potential bias may have been introduced through non-response and attrition. A short form of the questionnaire sent to nonresponders indicated no difference in past year alcohol use between responders to the short form and those responding to the entire survey. ${ }^{32}$ Moreover, we minimised threats from selection bias through use of a direct standardisation procedure for all study measures that reflected adjustment along eight strata (gender by two age groups ( $<22$ compared with others) by two ethnic groups (white compared with others)), using each school's true demographic characteristic in a referent year. Furthermore, we controlled for response rate in the analyses and restricted analyses to colleges with response rates of $50 \%$ or greater. The response rate for individual schools was not associated with rates of heavy episodic drinking. ${ }^{32}$ Rates of heavy episodic drinking and other substance use were almost identical to rates obtained by other US surveys. ${ }^{62}$ Results were based on self report mailed questionnaires, which are subject to response bias. However, self report surveys are commonly used in

\section{Policy implications}

- Policy and prevention professionals working with youth/young adult populations should develop and evaluate a broader range of community strategies for preventing alcohol abuse.

- Included among promising strategies for demonstration evaluation and possibly widespread dissemination should be those that support patterns of engagement among youth for the larger community, development of service learning and volunteer programmes for youth as part of their higher educational and school experiences.

- Building communities through promoting connections among youth and between youth and their surrounding institutions should be priorities for helping tackle prevalent problems of abuse of alcohol. examining alcohol use and are generally considered valid. ${ }^{43}$ Finally, the cross sectional design limits conclusions regarding directionality of associations.

\section{ACKNOWLEDGEMENTS}

Jeff Hansen from the HSPH helped prepare data files for this report. Comments on drafts of this manuscript from Toben F Nelson of the HSPH and two anonymous reviewers are acknowledged.

\section{Authors' affiliations}

E R Weitzman, Y-Y Chen, Department of Society, Human Development and Health, Harvard School of Public Health, Boston, Massachusetts, USA

Y-Y Chen, Taipei City Psychiatric Centre, Taipei, Taiwan

Funding: this study was supported by a grant from the Robert Wood Johnson Foundation.

Conflicts of interest: none declared.

\section{REFERENCES}

1 Hawkins JD, Catalano RF, Miller JY. Risk and protective factors for alcohol and other drug problems in adolescence and early adulthood: Implications for substance abuse prevention. Psychol Bull 1992;12:64-105.

2 Gruenwald PJ, Miller AB, Treno, AJ. Alcohol availability and the ecology of drinking behavior. Alcohol Health Res World, 1993;17:39-45.

3 Holder HD, Gruenewald PJ, Ponicki WR, et al. Effect of community-based interventions on high-risk drinking and alcohol-related injuries. JAMA 2000;284:2341-7.

4 Wagenaar AC, Toomey TL. Effects of minimum drinking age laws: review and analyses of the literature from 1960 to 2000 . J Stud Alcohol 2002:S14:206-25.

5 Goldman MS, Boyd GM, Faden V. College drinking, what it is, and what to do about it: a review of the state of the science, National Advisory Council on Alcohol Abuse and Alcoholism. J Stud Alcohol, 2002;S14. http:// www.collegedrinkingprevention.gov/Reports/TaskForce/ TaskForce_TOC.aspx (accessed 26 Mar 2003).

6 Johnston LD, O'Malley PM, Bachman JG. National survey results on drug use from the monitoring the future study, 1975-1995, Vol II. College students and young adults. NIH Publication no 98-4140. Rockville, MD: National Institute on Drug Abuse, 1997

7 Hingson R, Heeren T, Zakocs RC, et al. Magnitude of alcohol-related mortality and morbidity among US college students ages 18-24. J Stud Alcohol 2002;63:136-44.

8 Wechsler H, Moeykens B, Davenport A, et al. The adverse impact of heavy episodic drinkers on other college students. J Stud Alcohol 1995;56:628-34.

9 Wechsler H, Lee JE, Hall J, et al. Secondhand Effects of student alcohol use reported by neighbors of colleges: the role of alcohol outlets. Soc Sci Med 2002; 55:425-35.

10 Kuo M, Wechsler H, Greenberg P, et al. The marketing of alcohol to college students: the role of low prices and special promotions. Am J Public Health 2003;25:204-11.

11 Weitzman ER, Folkman A, Folkman KL, et al. The relationship of alcohol outlet density to heavy and frequent drinking and drinking-related problems among college students at eight universities. Health Place 2003;9:1-6.

12 Weitzman ER, Nelson TF, Wechsler H. Taking up binge drinking in college: the influence of personal, social and environmental factors. J Adolesc Health 2003;32:26-35.

13 Weitzman ER, Nelson TF, Lee $\mathrm{H}$, et al. Reducing drinking and related harms in college: evaluation of the "a matter of degree" program. Am J Prev Medicine 2004;21:187-96.

14 Putnam RD. The prosperous community. Social capital and public life. Am Prospect 1993;13:35-42.

15 Cattell V. Poor people, poor places, and poor health: the mediating role of social networks and social capital. Soc Sci Med 2001;52:1501-16.

16 Lochner K, Kawachi I, Kennedy BP. Social capital: a guide to its measurement. Health Place 1999;5:259-70.

17 Putnam RD. Making democracy work. Civic traditions in modern Italy. Princeton, NJ: Princeton University Press, 1993.

18 Wolf F. Predictors of myocardian infarction over a span of 30 years in Roseto, Pennsylvania. Integr Physiol Behavi Sci 1992;27:246-57.

19 Bronfenbrenner U. The ecology of human development: experiments by nature and design. Cambridge, MA: Harvard University Press, 1979.

20 Earls F, Carlson M. The social ecology of child health and well-being. Annu Rev Public Health 2001 ;22:143-66.

21 Kawachi I, Berkman LF. Social ties and mental health. J Urban Health: Bulletin of the New York Academy of Medicine 2001;78:458-67.

22 Kawachi I, Kennedy BP, Lochner K, et al. Social capital, income inequality, and mortality. Am J Public Health 1997;87:1491-8.

23 Weitzman ER, Kawachi I. Giving means receiving: the protective effect of social capital on binge drinking on college campuses. Am J Public Health 2000;90:1936-9

24 Aneshensel CS, Sucoff CA. The neighborhood context of adolescent mental health. J Health Soc Behav 1996;37:293-310. 
25 Donald M, Dower J. Risk and protective factors for depressive symptomatology among a community sample of adolescents and young adults. Aust N Z J Public Health 2002;26:555-62.

26 Hagerty BM, Williams RA, Coyne JC, et al. Sense of belonging and indicators of social and psychological functioning. Arch Psychiatr Nurs 1996; 10:235-44.

27 Sampson RJ, Raudenbush SW, Earls F. Neighborhoods and violent crime: a multilevel study of collective efficacy. Science 1997;277:918-24.

28 Jencks C, Mayer S. The social consequences of growing up in a poor neighbhorhood. In: Lynn LE, McGeary MFH, eds. Inner-city poverty in the United States. Washington, DC: National Academy Press, 1990:111-86.

29 Lonczak HS, Huang B, Catalano RF, et al. The social predictors of adolescen alcohol abuse: a test of the social development model. J Stud Alcohol 2001;62:179-89.

30 Wechsler H, Dowdall GW, Davenport A, et al. Correlates of college studen binge drinking. Am J Public Health 1995:85:921-6.

31 Wechsler H, Davenport A, Dowdall G, et al. Health and behavioral consequences of binge drinking in college. A national survey of students at 140 campuses. JAMA 1994;272:1672-7.

32 Wechsler H, Lee JE, Kuo M, et al. College binge drinking in the 1990s: a continuing problem. Results of the Harvard School of Public Health 1999 College alcohol study. JACH 2000;48:199-210.
33 American Psychiatric Association. Diagnostic and statistical manual of mental disorders. 4th ed. Washington, DC: American Psychiatric Association, 1994.

34 Weitzman ER, Wechsler $\mathrm{H}$. Alcohol use, abuse and related problems among children of problem drinkers. Findings from a national survey of college alcohol use. J Nerv Mental Dis 2000;188:148-54.

35 Wechsler H, Dowdall GW, Davenport A. A gender-specific measure of binge drinking among college students. Am J Public Health 1995;85:982-5.

36 Wechsler H, Nelson TF. Binge drinking and the American college student What's five drinks? Psychol Addictive Behaviors 200, 15:287-91.

37 Nelson TF, Wechsler H. School spirits: alcohol and collegiate sports fans. Addictive Behaviors 2003;28:1-11.

38 Goldstein H. Multilevel statistical model. London: Edward Arnold, 1995

39 Rasbash J, Browne W, Goldstein H, et al. A user's guide to MLwiN. London: Multilevel Models Project, Institute of Education, University of London, 2002.

40 Putnam RD. Bowling A. The collapse and revival of American community New York: Simon and Schuster, 2000.

41 Wechsler H, Kuo M. Watering down the drinks: the moderating effect of college demographics on alcohol use of high-risk groups. Am J Public Health 2003:93:1929-33.

42 Douglas KA, Collins JL, Warren C, et al. Results from the 1995 National College Health Risk Behavior Survey. JACH 1997;46:55-66.

43 Midanik L. Validity of self-report alcohol use: a literature review and assessment. Br J Addict 1988:83:1019-30.

\section{Register now!}

10th European Forum on Quality Improvement in Health Care

13-15 April 2005, ExCel Conference Centre, London

For further information on how to register please go to:

http://www.quality.bmipg.com 